\title{
IN SEARCH OF SOCIO-HISTORICAL ROOTS OF SOUTHEAST ASIA'S ISLAMIST TERRORISM With Special Reference to an Indonesian Experience
}

\author{
Sumanto Al Qurtuby \\ Boston University, Boston - USA
}

\begin{abstract}
This paper examines socio-historical roots of Southeast Asia's Islamist terrorism. Specifically focusing on cases of terrorism in Indonesia, it deals with global, regional, and local factors that underline the emergence of "radical Islamism" as the roots of modern terrorism. Although there had been some connections between Southeast Asia's militant Islamists to Afghanistan-based jihadists, an emphasis on the Al-Qaeda-centric paradigm as a framework for analyzing the rise of the region's terrorism is over-exaggerated. This analytical emphasis tends to ignore the international, regional and local agencies outside Al-Qaeda as well as local political dynamics and sociohistorical grounds that have contributed to the appearance of radical Islamism. Subscribing to Edward Said's "travelling theory", this paper argues that the idea of terrorism travels, not only from "person to person, from situation to situation, from one period to another" in a socio-historical vacuum, but also in response to specific historical and social changes. The idea of "radical Islamism" travels particularly from Afghanistan and elsewhere to Southeast Asia, especially Indonesia.
\end{abstract}

Keywords: Islamist terrorism, radical Islamism, jiha

\section{Introduction}

In the wake of the September 11 attacks on the World Trade Center of New York and the Pentagon of Washington, the US is taking a renewed interest in Southeast Asia's 'Second Front' in the 'War on Terror' project, declaring such organizations as Jama'ah Islamiyah (JI) and Abu Sayyaf Group (ASG) of the Philippines "foreign terrorist organizations" having links to Osama Bin Laden and 
Afghanistan-based Al-Qaeda. ${ }^{1}$ In response to these terrorist attacks, the United States, under the Bush administration, proclaimed the global "war on terrorism," 2 and invited other countries to join this campaign against (Muslim) terrorists that, according to Bush and his allies, have threatened worldwide human's security as well as international peace and stability. Specifically, the US government blamed Al-Qaeda-linked terrorist groups as the doers of the deadly attacks that resulted in some 3,000 casualties.

The US furthermore listed a number of radical Muslim groups considered to be Foreign Terrorist Organizations, some of which included Al-Qaeda (Afghanistan), ASG (the Philippines), JI (Indonesia), Hamas (Palestine), Hezbollah (Lebanon), and Ikhwanul Muslimin (Egypt). Of these terrorist organizations, Al-Qaeda has been viewed as the most dangerous and widespread terrorist group operating in wide-reaching major countries including those of Southeast Asia. ${ }^{3}$ The United Nations, moreover, adopted Resolution 1267 that made provision for the United Nations Monitoring Group to preserve a consolidated list of individuals and entities that were part

1 Zachary Abuza, Militant Islam in Southeast Asia: Crucible of Terror (Boulder, Colo.: Lynne Rienner, 2003), pp. 38-40; Idem, “Tentacles of Terror: Al-Qaeda's Southeast Asian Network," Contemporary Southeast Asia 24, 3 (2002b).

2 It is significant to note that there is no an agreed definition of what constitutes terrorism. The international community and body such as the United Nations (UN) or Organization of Islamic Conference (OIC) have failed in its attempts to adopt a convention defining precisely what is meant by terrorism. Thayer distinguishes the term "old terrorism" from that of "new terrorism." For him, the term "old terrorism" relates to selective political violence committed by anti-government insurgents and ethno-nationalist separatists, usually acting in isolation, and was confined in geographic scope's essay. "New terrorism," by contrast, refers to high-profile mass causality (apocalyptic) attacks against civilians by internationally networked terrorist groups. See Carlyle A. Thayer, "Leadership Dynamics in Terrorist Organizations in Southeast Asia” (Kuala Lumpur, Malaysia: Center for Defense Leadership Studies, 2005); Damien Kingsbury (ed), Violence in Between: Conflict and Security in Archipelagic Southeast Asia (Clayton and Singapore: Monash Asia Institute and Institute of Southeast Asian Studies, 2005), p. 53. In addition to this characterization, there is also "state terrorism" which refers to violence and coercion committed or sponsored by a ruling government to weaken and destroy opposing and resisting forces of the regime which they perceived to be potential to threaten, delegitimize and destabilize their state. See Bruce Hoffman, Inside Terrorism (New York: Columbia University Press, 1998), pp. 13-44.

3 Angel Rabasa, Beyond Al-Qaeda: Countering Terrorist and other non-Traditional Threats (Santa Monica, CA: The RAND Corporation, 2007); Idem, Political Islam in Southeast Asia: Moderates, Radicals, and Terrorist (Curzon: Routledge, 2003). 
of, or associated with, Afghanistan's Taliban and Al-Qaeda. Besides listing some 272 persons linked to Al-Qaeda, the United Nations, like the U.S., more specifically, has designated ASG and JI as Southeast Asia's terrorist groups that have strong ties to Afghan jihadists. ${ }^{4}$

Just as the United States and the United Nations, an international terrorism expert, Rohan Gunaratna, ${ }^{5}$ also asserts the central role played by Osama Bin Laden (hereafter Bin Laden) and Al-Qaeda in the spread of global terrorism. ${ }^{6} \mathrm{He}$ argues that Al-Qaeda is the "axis of global terrorism" including in Southeast Asia, and Bin Laden is portrayed as a chief executive officer (CEO) presiding over a global terrorist organization composed of Al-Qaeda members and leaders of Southeast Asian militant Islamic groups. Jane Corbin also points out that $\mathrm{Al}$-Qaeda was run like a business conglomerate or multinational corporation under the directorship of Bin Laden, who served as CEO of the "terrorist company." Corbin analogues Al-Qaeda to the Saudi Binladen's construction company founded by the father of Bin Laden. ${ }^{7}$

\section{Examining Al-Qaeda-Centric Paradigm of Global Terrorism}

Although the above scholars' analyses help to understand international dimensions of Southeast Asia's terrorism, they fail to recognize, identify, and analyze regional and local aspects and political dynamics that led to violent acts of "Islamist terrorism."8 As well, their

${ }^{4}$ ICG (International Crisis Group), "Al-Qaida in Southeast Asia: the Case of the 'Ngruki Network' in Indonesia," Brussels: ICG Asia Briefing, 2002; idem., "Indonesia Backgrounder: Why Salafism and Terrorism Mostly Don't Mix.” Asia Report no. 83, September 152004.

5 Rohan Gunaratna, “Al-Qaeda's Ideology," in Hillel Fradkin, Hussain Haqqani, and Eric Brown (eds), Current Trends in Islamist Ideology (Washington, DC: Hudson Institute, 2005); Idem., Inside Al-Qaeda: Global Network of Terror (Columbia, NY: Columbia Univ. Press, 2002).

6 Zachary Abuza, an expert on terrorism, claims that Al-Qaeda is composed of a central leadership of around thirty individuals, an international network of twenty-four constituent groups, eighty front companies operating in fifty countries, and a membership of between 5,000 and 12,000 organized into cells in sixty different countries. See Zachary Abuza, "Al-Qaeda's Asian Web of Terror," Time (Asia) 160, no. 22 (2002): pp. 38-40.

7 See Jane Corbin, Al Qaeda: In Search of the Terror Network. That Shook the World (New York: Thunder Mouth Press/Nation Books, c2002), p. 33.

8 The term "Islamist terrorism" in this piece refers to any violent act against civilians or governments committed by Islamist groups or radical jihadists, either those having links to transnational radical groups or purely local-based terrorists (cf. Abou El Fadl 
judgment about Bin Laden and Al-Qaeda-centric global terrorism is a kind of exaggeration and simplification, albeit there had been some linkages between Southeast Asian (Muslim) terrorists and Afghanistanbased jihadist groups. Such an Al-Qaeda-centric paradigm, moreover, fails to comprehend the dynamics, complexities, and history of local politics within Afghanistan and Southeast Asia. It should be kept in mind that Al-Qaeda emerged as an international jihadist terrorist organization in its own right only after Bin Laden (born in 1957) returned to Afghanistan in May 1996. He came back to this country after spending a period of time in an exile in Sudan, accompanied by Ayma al-Zawałri>(b. 1951, a well-known hardliner and the mastermind of the Egyptian Islamic Jihat, later becoming the AlQaeda's ideologue) and a large number of Arab Afghan jihadists.

More specifically, Al-Qaeda was transformed into a global terrorist group since this organization was led by al-Zawałiri $>$ Al-Zawałri $>$ filled the leadership of Al-Qaeda following the death of 'Abdulla Azzam (1941-1989), the ideological father of Al-Qaeda, who was assassinated by the Egyptian members of Al-Qaeda in Peshawar, Pakistan. Under al-Zawałris leadership, the new ideology of AlQaeda was marked by enthusiasm to carry out armed struggles against the perceived adversaries of Islam. ${ }^{9}$ This new ideology of Al-Qaeda's

2005). Unlike other forms of terrorism, Islamist terrorism has typically been characterized by ideologically-motivated actions, that is, to revive Islam from outside influences, to "clean up" the world from "earthly feces," and finally to establish an Islamic state based on the Qur'an and Shari'a. The use of the term "Islamist terrorism," instead of "Islamic terrorism," suggests that this particular sort of terrorism has nothing to do with "Islamic religion," but rather is linked to a certain group of Muslims known as radical Islamists or militant jihadists. See Mark Juergensmeyer, Terror in the Mind of God: The Global Rise of Religious Violence (Berkeley, CA: University of California Press, 2003); Mahmood Mamdani, Good Muslim, Bad Muslim: America, the Cold $W$ ar, and the Roots of Terror (New York: Pantheon Books, 2004). The definition of Islamist terrorism I sketched above, thus, covers what Marc Sageman calls salafi jihadism which represents a radical fringe of global salafi movement. Sageman points out that salafi jihadism (global salafi jiha) is a new development in the history of terrorism in part because it combines fanaticism (excessive enthusiasm in religious belief) with the terrorism against both the "near enemy" (local secular governments or Muslims outside their groups) and the "far enemy" (foreign governments and their populations) in pursuit of the salafi objective of building an Islamic state (or caliphate). See Marc Sageman, Understanding Terror Networks (Philadelphia, PA: Univ. of Pennsylvania Press, 2004).

${ }^{9}$ Gunaratna, “Al-Qaeda’s Ideology”; Abuza, Militant Islam in Southeast Asia. 
jihadism, conventionally traced to the work of two militant Sunni thinkers: Muhłmmad b. 'Abd al-Wahha (1703-1792, the founder of Wahhabism) and Sayyid Qut\} (1906-1966, an Egyptian ideologue who radicalized Ikhwanul Muslimin and is widely acknowledged as the father of militant jiha ${ }^{10}$ has been echoed by the worldwide radical jihadist Islamist groups from the Middle East to Indonesia.

It is important to note that Al-Qaedawas, initially, not a "terrorist group" utilizing suicide bombings to blow up "secular" buildings and target innocent civilians of non-Muslims of the western or eastern origins. Instead, this organization was, at first, set up to do jiha in the sense fighting against those who invaded Muslim territory or those who repressed Muslim communities. To put it differently, the origin of the establishment of Al-Qaeda was to conduct "defensive jihał." When Azzam, a Jordanian member of the Palestinian Muslim Brotherhood and reportedly a founder of Hamas, formulated the founding charter of Al-Qaeda (perhaps early 1988, shortly before the Soviets withdrew from Afghanistan), he envisaged Al-Qaeda (literally "Al-Sulbah"- - the "Solid Base") as an organization that would channel the energies of the Afghan mujaridiæ into fighting on behalf of worldwide oppressed Muslims. ${ }^{11}$ In short, the formation of Al-Qaeda was to serve as a "new vanguard group" for Islamic ummah. Azzam, one of the former Bin Laden's teachers at King Abdulaziz University, envisioned a revolutionary Muslim vanguard (read, Al-Qaeda) in part because he envisaged that it would overturn un-Islamic regimes in the Arab and the Middle East and establish an Islamic rule.

In April 1988, Azzam depicted his original concept of Al-Qaeda as follows:

Every principle needs a vanguard to carry it forward and, while focusing its way into society, puts up with heavy tasks

\footnotetext{
${ }^{10}$ Khaled Abou El Fadl, The Great Theft: Wrestling Islam from the Extremists (New York, NY: HarperSanFrancisco, 2005); Ahmad S. Mousalli, Radical Islamic Fundamentalism: The Ideological and Political Discourse of Sayyid Qutb (Beirut: American University of Beirut, 1992).

11 Ahmad Rashid, Taliban: Militant Islam, Oil and Fundamentalism in Central Asia (Yale: Yale University Press, 2001); Ibid., Descent Into Chaos: The United States and the Failure of Nation Building in Pakistan, Afghanistan, and Central Asia (New York: Viking Penguin, 2008).
} 
and enormous sacrifices. There is no ideology, neither earthly nor heavenly, that does not require such a vanguard that gives everything it possesses in order to achieve victory for this ideology. It carries the flag all along the sheer, endless and difficult path until it reaches its destination in the reality of life, since Allah SWT has destined that it should make it and manifests itself. Al-Qaeda Al-Sulbah constitutes this vanguard for the expected society. ${ }^{12}$

While the concept of Al-Qaeda was transformed to meet the changing geopolitical landscapes, Azzam did not originally intend it to be a global terrorist organization. He was reportedly to be a firm believer that "the end does not justify the means." During the AfghanSoviet war, for instance, Azzam rejected a proposal by Egyptian members of Maktab al-Khidmah li al-Mujatidi al-'Arab (MAK) which was widely known as the Afghan Service Bureau to utilize jihac $>$ funds to train the mujaridi terrorist ways, strategies, and tactics. He even issued a fatwa stating that such terrorism is a violation of Islamic law. Believing in jihas a religious obligation in defense of Islam and Muslims against defined enemies and not a speculative one, Azzam was against "the killing of non-combatants and would never endorse Al-Qaeda's current spate of terrorist tactics".13 Although Azzam was the ideological father of Al-Qaeda and former Bin Laden's mentor since the Soviet invasion of 1979 and the creation of the MAK, later, Bin Laden gradually transformed leadership of the organization. Toward the end of the anti-Soviet-Afghan campaign, Bin Laden's relationship with Azzam deteriorated. The peak of conflict between Azzam and Bin Laden, moreover, was when Azzam supported the "Lion of Panjshir" Ahmad Shah Massoud (1953-2001) while Bin Laden preferred Gulbuddin Hekmatyar (b. 1947), one of the most controversial of the mujatidiæleaders who once had been accused of spending more time fighting other mujatip than killing Soviets. Finally, the conflict between Azzam and Bin Laden had been resolved, not by democratic and peaceful means, but by the assassination of Azzam in 1989.14

\footnotetext{
12 As cited in Gunaratna, “Al-Qaeda’s Ideology,” p. 61.

13 Gunaratna, Inside Al-Qaeda, p. 2.

14 Gunaratna, "Al-Qaeda’s Ideology”; Rabasa, Beyond Al-Qaeda; Abuza, Militant Islam in Southeast Asia.
} 
Thus, it is obvious that since al-Zawatriri>became the new ideologue of Al-Qaeda and the new mentor of Bin Laden following the murder of Azzam, Al-Qaeda has shifted to a new form of jihadism and has turned to become an agent of global terrorism. Both Bin Laden and al-Zawałri łave the same passion: transforming Al-Qaeda into a global jihadist terrorist group to drive out secular regimes and western infidels alike in the name of Islam. In August 1996, Bin Laden issued a Declaration of Jiha whose goals were "to drive U.S. forces out of the Arabian peninsula, overthrow the Saudi government, and liberate Islam's holy cities of Mecca and Medina, as well as support revolutionary groups around the world." 15 The declaration states: "The walls of oppression and humiliation cannot be demolished except in a rain of bullets.". ${ }^{16}$ Since the declaration Al-Qaeda shifted its focus and meaning of jiha from the "near enemy" and defensive jiha to the "far enemy" and offensive one: war against the Americans and their 'infidel' allies. In 2000, Bin Laden announced the shape of the World Islamic Front for the Jiha against Jews and Crusaders, un umbrella group of Islamist radical movements across the world, and issued a fatwa obligating all Muslims to kill Americans and their allies that formed what he called a Judeo-Christian conspiracy. ${ }^{17}$ At the same year, interestingly, JI created Rałit al-Mujałdiæ (Legion of Mujalidiar), an umbrella organization of Southeast Asian Islamist groups engaged in armed struggle. ${ }^{18}$

It is significant to note that Southeast Asian Muslim militants, particularly those associated with JI and ASG, first journeyed to northern Pakistan and Afghanistan in 1980s, ${ }^{19}$ just a year after the

\footnotetext{
${ }^{15}$ John L. Esposito, Unholy War: Terror in the Name of Islam (New York, NY: Oxford University Press, 2002), pp. 20-1.

16 As quoted in Rashid, Taliban, p.133,

${ }^{17}$ Esposito, Unholy War, p. 21.

18 The members of the Legion of Mujatidiæincluded MILF, Free Aceh Movement (known as GAM-Gerakan Aceh Merdeka), Rohingiya Solidarity Organization, Araken Rohingiya Nationalist Organization, and Jemmah Salafiya (Thailand).

19 Greg Barton, Indonesia's Struggle: Jamaah Islamiyah and the Soul of Islam (Sidney: University of New South Wales Press, 2004); Thayer, "Leadership Dynamics in Terrorist Organizations"; ICG (International Crisis Group), "The Philippines: Counter-Insurgency versus Counter-Terrorism in Mindanao," Asia Report No. 152, May 142008.
} 
Soviet Union invaded Afghanistan, a country that has been called a "highway of conquest". ${ }^{20}$ This means that the contact between Southeast Asian radical Islamists with Afghan jihadists was at least eight years before Al-Qaeda was founded (in 1988) and eighteen years prior to the launching by Bin Laden of his global jiha against the far away foes of the "Western infidels." The Soviet Union invaded Afghanistan at the end of 1979 in part because it had distrusted the leadership of radical Khalqis that dominated PDPA (the Peoples Democratic Party of Afghanistan) government since it took power in a bloody coup de tat in 1978 that caused the murder of Mohammed Daud Khan.

As Barfield has noticed, the militant Khalqis controlled the PDPA rule were not just interested in governing Afghanistan but in "transforming the country through revolutionary policies of land reform, education, and changes in family law." In an attempt to impose their radical policies, moreover, the Khalqis attacked and wiped out all who opposed them, including "their Parchami rivals, the traditional rural landowners, the old military establishment, and Islamic clergy." More significantly, the Khalqis refused Afghanistan's traditional Islamic symbols of authority and legitimacy by "striking religious salutations from their speeches and decrees and changing the color of the flag to red." As a result, when the regime tried to implement its peculiar and radical policies in the countryside they were met with fight and resistance that quickly turned the country to massive uprisings that led to out of control. In this critical moment, driven by the desire to restore stability and bring the communist government back in, the Soviets intervened by occupying the country. They quickly removed and replaced the Khalqi with Parchami leadership under Babrak Karmal, and then were involved in an extensive war against the Afghan fighters as an effort to impose the new regime into submission and to drive them out the country. ${ }^{21}$

It was during this early period of the Soviet-Afghan war that Southeast Asian radical Islamists forged personal ties with leading figures in the mujatidiæ of Afghanistan. One particular influential figure was Abdul Rasul Sayyaf (b. 1946), a Pasthun warlord and leader

20 Thomas Barfield, "Problems in Establishing Legitimacy in Afghanistan," Iranian Studies 37, 2 (2004): p. 263.

${ }^{21}$ Ibid., pp. 280-2. 
of Islamic Union for the Liberation of Afghanistan (founded in late 1970s, later renamed the Islamic Dakwah Organization of Afghanistan), a radical salafi party supported by Saudi Wahhał> funding. It was under Sayyaf's patronage that key leaders of JI and ASG were trained at his camp in Afghanistan. Sayyaf provided training facilities to the bulk of Southeast Asia's Muslim militants while Bin Laden was in exile in Sudan (1991-1996). It was Abdul Rasul Sayyaf, member of the Afghan-based Ikhwanul Muslimin founded by Gulbuddin Hekmatyar (b. 1947, the founder of Hezb-e-Islami) and Burhanuddin Rabbani (b. 1940, the leader of Jamiat-e-Islami Afghanistan) (cf. Ewans 2002), who inspired the foundation of Abu Sayyaf Group (ASG) in the southern Philippines. The name of Abu Sayyaf (lit., the "father of the sword") was derived from the kunya (honorific name in place of given name) adopted by Abdurajak Janjalani, one of the founders of ASG, when he named his oldest son Sayyaf, thereby becoming Abu Sayyaf or the "father of Sayyaf." Abdurrajak Janjalani (d. 1998) named his son after he met Abdul Rasul Sayyaf, who ran the training camp he attended in Afghanistan. ${ }^{22}$ In 1990, Janjalani also met Bin Laden's brother-in-law Muhłmmad Jama $\triangleright$ Khalia, then heading the Philippines office of the International of Islamic Relief Organization ${ }^{23}$ (IIRO). Khalifa began directing funds his way and eventually drew him into an Al-Qaeda cell in the Philippines that included Ramzi Yousef, the 1993 W'TC bomber, and Yousef's uncle, 9/11 mastermind Khalid Sheikh Mohammad.

Established in the mid-1980s by a number of Afghan war veterans and members of Moro National Liberation Front (henceforth MNLF, founded in 1971 by Nur Misuari), ASG was originally known as the Muja Commando Freedom Fighters (MCFF) or al-Harakah alIslamizarb (the "Islamic Movement). In 1991, MCFF was renamed Abu

22 Kit Collier, "Dynamics of Muslim Separatism in the Philippines," in Damien Kingsbury (ed.), Violence in Between: Conflict and Security in Archipelagic Southeast Asia (Clayton and Singapore: Monash Asia Institute and Institute of Southeast Asian Studies, 2005); ICG (International Crisis Group), "The Philippines."

${ }^{23}$ IIRO was the most famous nongovernmental organization that channeled funds from two banks: Dar al- Mal al-Islami (founded by Prince Mohammed Faisal in 1981) and Dalla al-Baraka (established by King Fahd's brother-in-law in 1982) to assist fighting and relief services during the Afghan-Soviet war. IRRO functioned under the umbrella of the World Islamic League, led by Wahabi radical cleric Mufti Abdul Aziz bin Baz. 
Sayyaf Group (or Jama'ah Abu Sayyaf). The establishment of ASG was partly because Janjalani, a charismatic preacher in the mosques and madrasas of Zamboanga and Basilan of the Philippines, opposed the ideas of peace talks posed by Nur Misuari of MNLF.24 Janjalani insisted that the sole objective of the Muslim struggle was the establishment of an Islamic state, and not autonomy, independence, or revolution as MNLF did. Has been the principal target of the U.S. government, ASG, however, in reality is not political motivated insurgency or religious-driven rebellion in the same sense as the MNLF or Moro Islamic Liberation Front (hereafter MILF, founded in 1977). ${ }^{25}$

Based in and around the southern islands of the Philippines, particularly in the region of Bangsamoro (Jolo, Basilan, and Mindanao), ASG is best understood as a "network of networks," an alliance of smaller groups around individual charismatic leaders who "compete and cooperate to maximize their reputation for violence and terrorism: the bigger the violence, the bigger the pay-off, in terms of higher ransom payments and foreign funding". ${ }^{26}$ Contrary to some assumptions, the ASG was not an Islamist uprising that "degenerated" into criminality following the death of its founder, Aburajak Janjalani, in 1998. After the death of Janjalani, ASG was headed by his younger brother, Khaddafy Janjalani (d. 2006). Under the leadership of Khaddafy, ASG was marked by kidnapping, murders, and robberies as part of its modus operadi to get funds. Its religio-political activities and terrorism, however, did not die following Janjalani's death.

Another leading figure of the southern Philippines' jihadists by the name of Hashim Salamat, the founder of MILF also encountered Abdul Rasul Sayyaf when they studied in Al-Azhar University of Egypt. Died in 2003, Salamat also joined the Afghan mujałidiæduring

\footnotetext{
${ }^{24}$ MNLF, led by Nur Misuari, is the largest grouping of armed separatists fighting against the government of the Philippines. Under the auspices of the Organization of Islamic Conference and Muammar Qaddafi of Libya, the Marcos rule held negotiations with the MNLF reaching a treaty known as the "Tripoli Agreement" in 1976. The pact contains, among other, an agreement in which each group would stop fighting and the southern Philippines would be granted as an autonomous Muslim region. Unfortunately, the Marcos regime never honored the accord. See Kingsbury (ed.), Violence in Between, pp. 44-5.

25 Ibid.

${ }^{26}$ ICG (International Crisis Group), “The Philippines,” p. 7.
} 
a ten-year jiha to expel the Soviet Union. ${ }^{27}$ The MILF is a fragment of the Moro National Liberation Front (MNLF, founded in 1971 by Nur Misuari), the oldest separatist group in the region. The foundation of the MILF was due to a leadership dispute and ideological differences of its founder (Hashim Salamat) with Nur Misuari of MNLF. Having contacts with a number of international jihadist groups, including JI, MILF is a political movement with the banner of an Islamist ideology. ${ }^{28}$

Like the Philippines's leaders and activists of MILF and ASG, JI's members in Indonesia, Singapore, and Malaysia were ex-combatants of the Afghan wars and alumni of Pakistan's Deobandi madrasas. They also claim of having contacts with Afghan jihadist leaders. In December 2001, about three months after the 9/11 attacks, Singapore

27 See Thayer, "Leadership Dynamics in Terrorist Organizations." One of the most leading figures after the death of Hashim Salamat (d. 2003) is Mugasid Delma alias Abu Badrin, a classmate of Umar Petek, another terrorist associated with JI, in Afghanistan. Both were in the same intake at the JI military academy in Sada, Pakistan, on the Afghan border, in 1991. Other members of that class were the bombers of the 2002 Bali Blasts: Imam Samudra, Ali Imron alias Mukhlas (both, along with Amrozi, had been shot by a firing squad in October 2008), Sarjiyo alias Sawad, as well as Aris Munandar, leader of KOMPAK, an aid agency which reportedly funded by Muslim Aid in Britain. After the academy was forced to disband in 1992, Mugasid moved to Afghanistan's Torkhman with a group of JI members including Petek, Abu Dujana, and Zarkasih, the JI leaders arrested in June 2007. When Fathur Rahman al-Ghozi (born in Madiun, East Java), one of JI's most senior operatives, was shot dead at a checkpoint outside Cotabato city in October 2003, Mugasid reportedly was riding the lead motorcycle in his convoy. This explanation suggests that there had been some links between Indonesia-based JI and the Philippines-based terrorist groups such as MILF and ASG. Such close link can be understood since most of the members of those terrorist groups were the Soviet-Afghan war veterans, alumni of Afghanistan's paramilitary camps, and graduates of Pakistan's Deobandi madrasas. JI also built a military academy known as Camp Hudaibiyah, a camp for foreign fighters located within Camp Abu Bakar, in the southern Philippines in 1994, to replace its Afghanistan facilities and bases. In 1998, the camp became the headquarters of JI's territorial sub-division in the region so-called Mantiqi III which its territory covered Indonesia's Sulawesi and East Kalimantan as well as Malaysia's Sabah. See ICG (International Crisis Group), “The Philippines.” When Camp Abu Bakar was overrun by the Philippines' authorities in the summer of 2000, JI members moved its training and bases in Central Sulawesi's Poso, one of the frailest places in Indonesia suffered by Christian-Muslim wars. See Lorraine V. Aragon, "Communal Violence in Poso, Central Sulawesi: Where People Eat Fish and Fish Eat People," Indonesia 72 (2001): pp. 45-79.

${ }^{28}$ Rashid, Taliban, p. 128. 
authorities arrested fifteen Muslim militants suspected of working with Al-Qaeda who planned to bomb a shuttle bus service carrying U.S. military personnel and U.S. naval vessels in Singapore. Later, a videotape found in Afghanistan confirmed the "Singapore connection." Thirteen of the Singapore detainees, eight of which reportedly had training in Afghanistan's Al-Qaeda camps, were said to be members of a cell of an organization that authorities identified as JI. In a speech in May 2002, Lee Kuan Yew states:

Interrogation [of the suspects detained in Singapore] disclosed that Abu Bakar Ba'asyir, the [former] leader of the Indonesian Muja overall leader of the JI organization, which covered both Malaysia and Singapore. He was a member of Darul Islam, which aimed at the violent establishment of an Islamic state in Indonesia since the late 1940s. He was in Malaysia for 14 years to avoid detention by the Suharto government and returned in 1999 after Suharto fell from power. ${ }^{29}$

Since Singapore authorities arrested alleged JI members, particularly since Senior Minister Lee delivered that speech, attention shifted to Abu Bakar Ba'asyir (b. 1938), an Indonesian Islamist cleric of Yamani origin who was considered to be the new AmiralMu'minis (the "Leader of Believers") of JI. Since the death of Abdullah Sungkar (1937-1999), a charismatic leader of JI, Ba'asyir has become a "new celebrity" due to his central position as leader of both JI (he succeeded Sungkar after his death in 1999) and Majelis Mujahidin Indonesia (MMI). ${ }^{30}$ Established by Indonesian radical cleric of ( $\mathrm{H}\{\mathrm{d}$ rami $>$ Yamani origin by the name of Abdullah Sungkar in the early 1990s, JI was regarded by the United States and the United Nations as a regional terrorist network closely linked to Al-Qaeda. JI was also considered as the closest nexus between radical Islamism in Southeast Asia and the global jihadist movement.

Working on Indonesian politics and societies for decades, the Australian sociologist Greg Barton, however, underscores the dynamics of Indonesia's local politics as the roots of the formation of

\footnotetext{
${ }^{29}$ ICG (International Crisis Group), "Al-Qaida in Southeast Asia.”

30 The MMI is now split due to internal conflict between Ba'asyir and Irfan Awwas in terms of the groups' ideology. Finally, Ba'asyir established a new organization named Jama'ah Anshorussunah.
} 
JI. Specifically, Barton ${ }^{31}$ traces back the origins of JI to three Indonesia's Islamist and separatist groups: (1) Hizbullah (the "Party of God"), a militia set up during World War II to oppose the Dutch and then the Japanese (1942-1945); (2) Darul Islam (DI-the "Adobe of Islam"), a sort of re-embodiment of Hizbullah whose main objective was to establish an Islamic state in Indonesia known as Negara Islam Indonesia (Indonesian Islamic State); and (3) Komando Jihad (KJ-the "Jiha Command"), Islamist guerrillas and reincarnation of DI during the reign of Suharto-led New Order. Court documents from the 1980s also show that $\mathrm{KJ}$ referred to the founding of an organization, continuing from Darul Islam, as JI. After Sukarno cracked down the headquarters of DI in 1962, its members later were found to be dubbed by the New Order as KJ in 1976-77. In order to discredit the Islamists linked with PPP (the only Islamic party during the New Order) prior to the 1977 elections, the Suharto regime arrested 185 people associated with what the New Order called KJ group in mid1977. It was Gen. Ali Murtopo (1924-1984, the "Suharto man"), along with his officers within Indonesian intelligence agency (known at the time as BAKIN), who engaged in a "smart operation" that made the $\mathrm{KJ}$ activists (which were DI members) out of their hiding. At the time, Ali Mortopo said (persuaded exactly) to a handful of DI leaders that he needed members and activists of DI to blockade the influences of Communism in Indonesia. ${ }^{32}$

\footnotetext{
${ }^{31}$ Barton, Indonesia's Struggle.

32 The argument provided by Gen. Ali Murtopo-led intelligence agency was that, with the fall of South Vietnam in 1975, Indonesia was in danger of Communist infiltration across the Indonesian-Malaysian border in Borneo, and that only the reactivation of DI could protect Indonesia. Whether through coercion or bribe money (or both), a number of DI leaders rose to the bait, and by mid-1977, the government arrested 185 people whom it accused of belonging to a hitherto unknown organization called Komando Jihad (KJ), committed to following the ideals of Kartosoewirjo and establishing the Islamic State of Indonesia. In reality, the KJ was Ali Murtopo's creation. From the beginning, KJ or what the government called JI intersected, albeit it was unclear whether the government was attributing more structure to the latter than was in fact the case. KJ was the labeled applied by the government and the Indonesian media to the former DI fighters who never used it themselves. The term "JI" appears in court documents from the 1980 s to refer to the new organization that the DI men thought they were setting up. See Barton, Indonesia's Struggle; ICG (International Crisis Group), "Al-Qaida in Southeast Asia."
} 
Approaching DI veterans to fight against Communists is apt in part because they played a strong role in the assault against communism since the mid-1960s. DI members, along with other Islamic organizations, enthusiastically backed the CIA-orchestrated coup (1965-66) that installed the Suharto dictatorship and resulted in massacre of some 500,000 (other said between 1-2 million casualties) Communist Party members, workers, and sympathizers. ${ }^{33}$ The Suharto group portrayed the coup as, to borrow Hefner's words, an "irreligious communist plot against the nation" 34 in order to gain popular-religious support. Suharto, then, mobilized the country's Muslim groups, added by smaller groupings of Christians into an efficient campaign of mass killing. When the Soviet Union invaded Afghanistan in late 1979s, DI also sent some 350 fighters to join Afghan muja dim. Gaos Taufiq, Sumatra-based DI leader, revealed that Abdullah Azzam in a sermon in Mecca in the early 1980s invited worldwide Muslim jihadists to come to Afghanistan to do jiha against the communist regime and the Soviet Union. A number of Indonesian jihadists who heard Azzam's sermon promised him that they would get more recruits in Indonesia, especially from DI and the Indonesian Muslim Youth Movement (known as GPII-Gerakan Pemuda Islam Indonesia), a Wahabiaffiliated Muslim youth organization. In Pakistan and Afghanistan, DI members came into contact with Abdullah Azzam, who was the key of founding present-day International Legion of Islam, an umbrella organization of worldwide jihadist movements. ${ }^{35}$ Hence, it is impossible to have a broad picture of all modern-day Indonesia's jihadist movements without looking at the dynamics and complicated development of DI. Abu Bakar Ba'asyir draws inspiration from the DI rebellion in West Java in the 1950s and indeed he fully endorsed DI's political agenda, albeit he was not the member of DI. However, Abdullah Sungkar, the first amir of JI, was a former officer of Kartosoewirjo's Tentara Islam Indonesia (the "Islamic Army of

\footnotetext{
${ }^{33}$ Freek Colombijn and J. Thomas Lindblad (eds), Roots of Violence in Indonesia (Leiden: KITLV Press, 2002).

34 Robert W. Hefner, "Muslim Democrats and Islamist Violence in Post-Soeharto Indonesia," in Robert W Hefner (ed.), Remaking Muslim Politics: Pluralism, Contestation, and Democratization (Princeton and Oxford: Princeton University Press, 2005), p. 277.

35 Noor Huda Ismail, "Al-Qaeda's Southeast Asia, Jamaah Islamiyah and Regional Terrorism: Kinship and Family Likns," Japan Focus, January 8, 2007: pp. 3-10.
} 
Indonesia"), the military wing of DI (note: Kartosoewirjo's movement often called DI/TII).

As the New Order crashed Komando Jihad, its activists were jailed, murdered, or fled to other places/countries. Abdullah Sungkar and Abu Bakar Ba'asyir were among those detained by the government. Due to their meetings with Haji Ismail Pranoto (Hispran for short), a close friend of, and had been a commander under Kartosoewirjo and was accused of leading the KJ movement, they were both charged with having been inducted into DI by Hispran. Whether Ba'asyir and Sungkar were directly associated with KJ or not, both men were known for making statements urging disobedience to secular authorities and questioning the validity of the (secular) Indonesian constitution. In particular Ba'asyir and Sungkar rejected the state ideology of Pancasila and criticized Suharto's New Order. As a result, the government sentenced them to nine years in prison for subversion. They had been in detention since November 1978. When in late 1982, their sentences were reduced on appeal to three years and ten months, both men were released and then they returned to Pesantren Al-Mukmin, based in Ngruki, Central Java's Solo (hence known as Pondok Ngruki), an Islamic boarding school they founded in 1971 which later has become the primary networks and home-base of JI-related activities. ${ }^{36}$

Facing forthcoming re-arrest, Ba'asyir and Sungkar fled to Malaysia in April 1985, accompanied by a number of the "Ngruki Network," among them are Fikiruddin, Agus Sunarto, Rusli Aryus, Mubin Bustami, Fajar Sidiq, Muzahar Muhtar, and Agung Riyadi (later they were sent by Sungkar and Ba'asyir to join the Afghan war). In their views, they left for Malaysia is not to avoid (re) arrestment, but rather to do a religiously-inspired bijrah (emigration) to escape from the enemies of Islam, similar to the Prophet Muhłmmad's bijrah from Mecca to Medina in early seventh century. ${ }^{37}$ In Malaysia they met an Indonesian Afghan war veteran known as Abu Jibrili38 (alias Fikiruddin

\footnotetext{
36 Kumar Ramakrishna, "Delegitimizing Global Jihadi Ideology in Southeast Asia," Contemporary Southeast Asia 27, 3 (2005): pp. 343-69.

${ }^{37}$ Angel Rabasa, Political Islam in Southeast Asia: Moderates, Radicals, and Terrorist (Curzon: Routledge, 2003); Abuza, Militant Islam in Southeast Asia.

38 Born in Indonesia's East Lombok, Abu Jibril became well-known preacher at the Sudirman Mosque in Yogyakarta in early 1980s. He was captured by Malaysian authorities in 2002. Abu Jibril, a member of Indonesian Mujatidi Council, also
} 
Muqti or Muhammad Iqbal), with whom they established the Pesantren Luqmanul Hakiem, a clone of the Pondok Ngruki, in Ulu Tiram, Malaysia's Johor state, as a base for indoctrination and operations. In addition Ba'asyir and Sungkar met Abdul Wahid Kadungga, the son-in-law of Kahar Muzakkar, Sulawesi-based DI. Part of the DI network, Kadungga fled to Europe in 1971 and later founded the Muslim Youth Association of Europe.

Furthermore, Ba'asyir and Sungkar linked up with another Indonesian veteran of the Afghan war Riduan Isamuddin alias Hambali, who was reported to be the operational chief and conduit for funds from Al-Qaeda to JI (Hambali is Indonesian spelling of the Arabic word 'Hanbali,' which refers to the most dogmatic and traditionalist of the four Sunni school of law built based on the teachings of the legal scholar Ahrhad bin Hanbal, 780-855). It is said that Hambali, the only non-Arab member of the shurentral council) of Al-Qaeda, provided a critical link between the Indonesian Islamist militants of the Ngruki network and Bin Laden as well as Al-Qaeda. ${ }^{39}$ Through his contact with Sungkar, in 1986, Hambali was invited to go to Afghanistan both for training and helping mujatidiæfighting against the Soviet Union. While Hambali spent the next two months in

appears on a tape recruiting volunteers to fight in Maluku during the Muslim-Christian wars.

${ }^{39}$ Hambali played a central role in a number of terrorist bombings and violent acts in Indonesia and the Philippines. Since he held both Al-Qaeda and JI appointments, he also became a major link between the two terrorist organizations. Hambali's role was not only to channel both groups but also to funnel some funds from Al-Qaeda to JI. From 1998-2001, Hambali funneled some US\$12,000 to the MILF and some US $\$ 18,000$ to Muslim fighters in Indonesia's Ambon. He also provided Al-Qaeda funds to bomb specified targets in Southeast Asia including the Bali Blasts of 2002. Because of ongoing investigations in Indonesia and Malaysia, Hambali and his wife left Malaysia and travelled to Afghanistan via Bangkok (Hambali used his true name of Malaysian passport). After arriving in Karachi, they proceeded to Kandahar where they stayed for one month. While in Afghanistan, Hambali's primary contacts included Mohammed Atef, the military commander of Al-Qaeda (killed in November 2001) and Khalid Syeikh Mohammed. To assist Al-Qaeda's Anthrax program, Hambali recruited Yazid Sufaat, a U.S.-trained biochemist and a former Army Captain from Malaysia, who came to Afghanistan in June 2001. Yazid participated in a one-month training course and then began working with Hambali supporting the Anthrax program in Kandahar. Hambali was arrested by the Thai Special Branch upon his return to Malaysia and Indonesia. See ICG (International Crisis Group), "Al-Qaida in Southeast Asia”; idem., "The Philippines." 
Karachi, he met a number of individuals from Indonesia including Zulkarnaen who also became close to Al-Qaeda. Prior to his death, Abdullah Sungkar resent Hambali to Afghanistan to meet with Khalid Sheikh Mohammed, the mastermind of the $9 / 11$ operation, and several important Al-Qaeda members including Wali Amin Khan Shah, who worked with Ramzi Ahmed Yousef to destroy 12 U.S. airliners over the Pacific (the attack was thwarted). The purpose of the meeting was to strengthen the already established ties with Al-Qaeda and arrange for JI members to travel to Afghanistan to receive training. In addition to several journeys to Afghanistan, Hambali reportedly made two trips to Pakistan in 1999 (first journey was alone while his second trip was accompanied by Faiz Bafana, a JI member of Singapore origin). ${ }^{40}$ Hambali also reportedly travelled several times to Southern Philippines since early 1990s. There he met Syamsuddin, an Indonesian who subsequently brought him to the MILF Camp Abu Bakar, where he met MILF leader Hashim Salamat.

In addition to support the establishment of an Islamic state in Indonesia, Sungkar and Ba'asyir identified a number of sympathetic Malaysian businessmen and travelled to Saudi Arabia for fund raising. Additionally, they established contacts and relationships with the mujałidiæleaders in Afghanistan during the Soviet-Afghan war. This encounter opened the gateway for JI members to become even more politicized and radicalized. In Afghanistan, they also received military training and were exposed to the ideology of armed jihat. Sungkar and Ba'asyir, with Saudi funding, furthermore, sent volunteers recruited mostly from Indonesia, Singapore, and Malaysia to Afghanistan, southern Philippines, southern Thailand for guerilla training, and Pakistan for "religious indoctrination" of Islamism and jihadism. It was in the camps of the Saudi-financed Afghan Mujatidi leader Abdul Rasul Sayyaf that the senior members of then JI developed jihadist passion, global contacts, and deadly skills. ${ }^{41}$ It is reported that Andi Muhammad Taqwa and Abdullah Anshari (also known as Ibnu

40 Rabasa, Beyond Al-Qaeda; Zachary Abuza, "Tentacles of Terror: Al-Qaeda's Southeast Asian Network," Contemporary Southeast Asia 24, 3 (2002); idem., Militant Islam in Southeast Asia..

41 Gunaratna, "Al-Qaeda's Ideology"; ICG (International Crisis Group), "Jamaah Islamiyah in Southeast Asia: Damaged but Still Dangerous,” Asia Report No. 63 Jakarta and Brussels: International Crisis Group, 2003). 
Thoyib) were in charge to recruit the volunteers (they themselves travelled to Pakistan and Afghanistan to join the Afghanistan's mujatidim. The connection between the leaders of JI and Al-Qaeda does not cease by the end of the Afghan war. They reportedly visited one another. In the mid 1990s, Ayman al-Zawahiri of Al-Qaeda, for instance, visited and spent time engaging the JI leadership in Malaysia. In the second half of the 1990s, Sungkar and Ba'asyir visited Pakistan, where they met Bin Laden occasionally. ${ }^{42}$

JI itself was established by Sungkar in 1993 after a dispute between him and the Indonesian-based DI leader Ajengan Masduki. However, the name of JI was "officially" used in 1995. Sungkar looked to make a clean break from DI by adopting a different organizational framework and structure of JI. Initially JI was set up as a clandestine group whose long-term objective was to establish a transnational Islamic state (Daulah Islamiyyah) comprising Indonesia, Malaysia, and the southern Philippines. ${ }^{43}$ Members of his small but militant group included Hambali, Abdul Ghani, Jamsari, Suhauime, Matsah, Adnan, and Faiz Bafana (all the Afghan war veterans). In Malaysia, JI is known as Kumpulan Militan Malaysia (KMM-Malaysian Militant Community), formed by Hambali, Abu Jibril, and Zainon Ismail (another Afghan war veteran) around 1994-95. They focused their efforts on Indonesian migrants, students, and lecturers at Universiti Teknologi Malaysia (UTM) and other local Islamic schools. As Sungkar and Ba'asyir who sent volunteers to Pakistan or Afghanistan, they also sent young Islamist militants from Indonesia, Malaysia, and Singapore to Pakistan (particularly Deobandi-affiliated schools) for religious indoctrination and the MILF camps (especially Camp Hudaibiyah) in Mindanao for military training (note: since the Soviet-Afghan war ended, JI built a military base in the region of Mindanao of southern Philippines).

In order to preserve Islamist movements, the group was tied by ideology, training, and a complex network of marriages among their families. Such inter-marriage has facilitated JI to have a depth of leadership that provided a capacity for regeneration ${ }^{44}$ as well as a

42 John Sidel, Riots, Pogroms, Jihad: Religious Violence in Indonesia (Ithaca and London: Cornell University Press, 2006).

${ }^{43}$ Rabasa, Political Islam in Southeast Asia, p. 31.

${ }^{44}$ In his study on kinship and family links of Southeast Asia-based terrorist groups, Noor Huda Ismail discovers interesting findings of common inter-marriage among the members of jihadist groups. Abdullah Sungkar, for instance, married two of his 
means of maintaining their "identity" and continuation of their groups. Joining the jiha was a three-pronged process of social affiliation (social bonding) involving membership in "small-world" groups based on friendship, kinship, and discipleship. The British social anthropologist Abner Cohen once said that groups in modern societies utilized symbols link to kinship, friendship, and ritual to further and maintain their economic and political interests. ${ }^{45}$ Using Cohen's theoretical frameworks, JI (and other terrorist organizations) can be included as "interest groups" that preserve and develop its communities and mission through a complex mixture of kinship, comradeship, relationship, discipleship, religious ritual, association, education, informal mechanism and so forth in order to safeguard not only political and economic interests but also ideological concerns.

Despites inter-marriage, sending children and families to Pakistanbased Deobandi madrasas became "habitual actions" of senior JI members. The rationale for sending their children and relatives to those places is partly because they were worried about their offspring's safety and persistence, besides to rejuvenate JI. Deobandi madrasas became favorite destination for religious training and indoctrination of Southeast Asian jihadists mainly because these schools have been the hub of the dissemination of religious militancy and radical Islamism. Founded in 1867 in the North Indian town of Deoband by Maulana Qasim Nanotvi, the Deobandi began in the Indian subcontinent as a reformist movement. The Deobandi gained considerable strength during the anti-Soviet Afghan jiha in part because Gen. Zia al-Haq encouraged the establishment of madrasas for Afghan refugees as well as Pakistanis. With Saudi funding, particularly since the 1970s, the Deobandi madrasas have been the training ground for Al-Qaeda and radical Islamists and the vehicle of the spread of strict Wahabi

stepdaughters to senior jihadists; they are Ferial Muchlis bin Abdul Halim, a head of the Selangor JI cell, and Syawal Yasin, a prominent South Sulawesi figure and former trainer in Afghanistan. Sungkar himself had been the celebrant at the 1984 marriage of future Mantiqi 4 leader (Mantiqi refers to the "regional division" of JI) Abdul Rohim Ayub and the Australian Rabiyah. Harris Fadhilah, one of DI militia leaders who died during the Ambon wars of 1999-2001, arranged the marriage of his daughter, Mira Agustina, to Indonesia-based Al-Qaeda operative Omar Al-Faruq. See Ismail, "AlQaeda's Southeast Asia," pp. 1-11.

45 Abner Cohen, Two-Dimensional Man: An Essay on the Anthropology of Power and Symbolism in Complex Society (Berkeley, CA: University of California Press, 1974). 
teachings. The Deobandi's political expression and ideology, furthermore, were transformed within Pakistan's Jamiyyat-i-Ulama-iIslam, a religious party headed by Maulana Fazlur Rahman with a rigid, militant, anti-American, and anti-non-Muslim culture. ${ }^{46}$

In those madrasas, Southeast Asian jihadists formed so-called alGhuraba (the "foreigners") cell whose leader was Ba'asyir's son: Abdul Rohim. During university break, some members of the group went to Afghanistan for a course in urban warfare. They also travelled to Pakistan-controlled parts of Kashmir where Lashkar-e-Toiba, a guerilla movement affiliated with Al-Qaeda, gave them a month of physical and military training. One of the group's members was Abu Dzar whose father was a long-time colleague of Hambali. Two of Abu Dzar's uncles are also JI members in which one of them, Muhammad Isma'il Anwarul, also attended an Al-Qaeda training camp in Kandahar in 2001. Abu Dzar's sister had married to Masran bin Arshad, the leader of Khalid Syeikh Muhammd's allaged suicide cell. Another cell member was the Malaysian Muhammad Ikhwan, whose father, Abdullah Daud, attended an Al-Qaeda surveillance course in Kabul in 2000.47

As is well-known, the Muja didis victory over the Soviet Union in Afghanistan after 10 year wars was a watershed event for radical Islam. The Afghan jiha undoubtedly increased JI's military capabilities, their access to financial and other resource networks, and perhaps more importantly, their sense of belonging to an international Islamic brotherhood. The experience involved in the Afghan war in general and their contact with Al-Qaeda in particular boosted their desire for jihagainst what they saw as the enemies of Islam and Islamic ummah, namely the "Crusaders," the "Zionists," as well as the "apostate" and secular Muslim rulers. Unlike other Southeast Asian Islamist groups, JI at this stage was, to borrow Gunaratna's term, "an ideological hybrid". ${ }^{48}$

\footnotetext{
${ }^{46}$ Ahmad Rashid, Descent Into Chaos: The United States and the Failure of Nation Building in Pakistan, Afghanistan, and Central Asia (New York: Viking Penguin, 2008), p. 53; Esposito, Unholy War, p. 16;

${ }^{47}$ Ismail, “Al-Qaeda’s Southeast Asia”; ICG (International Crisis Group), "Al-Qaida in Southeast Asia."

48 Gunaratna, “Al-Qaeda’s Ideology,” p. 75.
} 
Despite its roots were in Southeast Asia, JI's ideological viewpoint became increasingly "Arabized" and developed a strong orientation toward the Middle East, most notably Saudi Arabia and Egypt. More specifically, JI began to incorporate the ideologies of the Egyptian AlJama'ah al-Islamiyah, a breakaway faction of the Egyptian Muslim Brotherhood (Ikhwanul Muslimin) committed to armed struggle, as well as the Egyptian Islamic Jiha into its own thinking. ${ }^{49}$ After the death of JI charismatic leader Abdullah Sungkar and Ba'asyir took the lead of JI, however, JI members began to split. The younger member of JI such as Hambali, Imam Samudra, Ali Gufron, and Amrozi (the three latter were trio Bali bombers and again the Afghan war veterans who were shot by a firing squad) saw Ba'asyir as "too weak, too accommodating, and too easily influenced by others". ${ }^{50}$ They also viewed the formation of MMI (the Indonesian Muja $\$$ Council), an umbrella organization of Islamist groups whose primary objective was to campaign for the enforcement of Shari'at in Indonesia, by Ba'asyir and Irfan Awwas in 2000 as a betrayal of Sungkar's original plan for JI to remain underground in its struggle to set up a global Islamic caliphate. JI's radicals objected to working with Muslim political parties that advocated Islamic law through elections and parliament because they saw this as an accommodation with non-Islamic (Indonesian) state that would "contaminate the faithful" and was therefore forbidden. Ba'asyir himself after the founding of MMI in August 2000 became so involved with MMI (later he split and founded a new group) and he turned over day-to-day running of JI to Abu Rusydan.

Following the massive detainment of the terrorists by Southeast Asian governments, added by internal conflicts, today's JI has become badly fractured organization in disarray. Nasir Abbas, former JI regional leader and "whistleblower" of JI networks (now in custody), says "JI is a ruin now...no management, no administration anymore." ${ }^{1}$

\section{Radical Islamism's Global and Local Elements}

The above explanation clearly shows the links between Southeast Asian Islamist terrorist groups and Afghanistan-based jihadists.

\footnotetext{
${ }^{49}$ Hefner, "Muslim Democrats and Islamist Violence," p. 292.

50 ICG (International Crisis Group), "Al-Qaida in Southeast Asia.”

51 As quoted in Thayer, "Leadership Dynamics in Terrorist Organizations," p. 26.
} 
However, linking Southeast Asia's terrorism merely to Bin Laden and Al-Qaeda as "international terrorism experts" argued is overemphasized. Such Al-Qaeda-centric paradigm ignores the varieties of violent acts and complexities of the roots of terrorism. Furthermore, this view neglects various agencies, ideologies, schools of thought, and resources-both local and international-that have considerably contributed to the acts of terrorism in present-day Southeast Asia. As described above, in addition to the influences of Afghan mujalidiæ (resistance fighters), modern-day Islamists are deeply rooted within "local dynamics," socio-history, and politics of Southeast Asia.

In a study on the Philippines' separatism, Kit Collier, for instance, makes an interesting argument. Rather than discussing "global Islamic ideology," Collier scrutinizes the local dynamics of the Philippines' politics as the key root causes "Muslim separatism" in the southern region of the country. Collier also argues that the competition over local nationalist identity (the "Morohood") posed by Muslim separatists and terrorist groups like the MNLF, MILF, and ASG with state identity is not driven by long-standing local politics, but rather more recent local political phenomena. ${ }^{52}$ In other words, the modern myth of Morohood and Islamic sentiments echoed by those Muslim separatists and terrorists are a form of present-day political mobilization or "social movement" for Muslim separatism by "exploiting" ethnic, cultural, and religious identity..$^{53}$

Mobilization either based on ethnicity, religion, or race, according to Olzak, ${ }^{54}$ is the capacity to tie together resources, including material resources and cultural/symbolic resources as well as organizations and solidarity, in an attempt to achieve some collective objectives. In the case of the Southern Philippines's "Islamist" mobilization, furthermore, these "collective objectives" vary ranging from the creation of the region's autonomy to the establishment of an Islamic state. In addition to a form of "ethnoreligious mobilization," the

\footnotetext{
52 Collier, "Dynamics of Muslim Separatism."

53 Thomas McKenna, Muslim Rulers and Rebels: Everyday Politics and Armed Separatism in the Southern Pbilippines (Berkeley, CA: University of California Press, 1998).

54 Susan Olzak, "Ethnic, Racial, and Nationalist Movements," in The Blackwell Encyclopedia of Sociology, vol. III, edited by George Ritzev (Malden, MA: Blackwell Publishing, 2007), p. 1465.
} 
Southern Philippines also can be defined as a sort of "nationalist movements" since the region's political actors, namely the MNLF, MILF, and ASG, commonly articulate claims over the legitimate and legal right to rule a specific geographical area, ${ }^{55}$ albeit in the case of post-Janjalani ASG the idea of "nationalist sentiments" was quite blurred. In the pursuit of "sovereignty rights," those radical organizations were involved in a series of violent conflicts with the region's existing governments since the Marcos regime. It is significant to note that actors of nationalist movements in claiming sovereign rights do not always depend on race or "shared grievances" (of colonial or post-colonial past, for instance) as commonly occurred in world's nationalist movements. Like in the case of the Southern Philippines, the nationalist movements can also be built based upon "ethnoreligious identity," namely "Moorohood" and Islam. Accordingly, using Olzak's theoretical framework, the Southern Philippines is a sort of "nationalistic Islamic movements." Ethnicity as well as religion becomes transformed into a sort of nationalist movements when ethnic and religious actors make "specific historical claims and attempts to administer the group as a political community." 56 As depicted above, in an attempt to establish a separate region and to get "public support," Southern Philippines's separatist groups also claimed the historical distinctiveness and ethnic uniqueness of Bangsa Moro. ${ }^{57}$

Seeing from a slightly different theoretical framework, the Southern Philippines's separatist movement was also a form of the "invention of tradition" in the service of an "imagined community," to borrow the famous term of the political scientist, Benedict Anderson. It is significant to notice that the foundation of the MNLF- the oldest separatist group-was only in 1971. This year coincided with the national elections and the southern Philippines had become an arena of elite competition, notably the two national political parties: Liberal and Nacionalista, as the centralizing regime of Ferdinand Marcos sought to tighten its grip on a rapidly expanding constituency in the

\footnotetext{
55 Olzak, "Ethnic, Racial, and Nationalist Movements"; Robert W. Hefner, Civil Islam: Muslims and Democratization in Indonesia (Princeton and Oxford: Princeton University Press, 2000).

56 Olzak, "Ethnic, Racial, and Nationalist Movements,” p. 1466.

${ }^{57}$ McKenna, Muslim Rulers and Rebels.
} 
South. Marcos, elected president under the banner of Naciolista in 1965, competed with a long-standing Liberal Party activist, Salipada Pendatun. The southern electorates became a major rivalry for Christian elites because Muslims are not dominant populace in the southern Philippines any more since Christian communities migrated to the region, particularly since 1946. Between 1918 and 1970, the Christian influx reduced Muslims from $60 \%$ to $28 \%$ of the population of the Cotabato region; from $91 \%$ to $61 \%$ of the Lanao region; and from $62 \%$ to just $13 \%$ in the Zamboanga region. ${ }^{58}$

Driven by local socio-political conditions that un-favored Muslim communities, during that time, the datus, local elite Muslim aristocrats who held religious authority on the basis of ancestral ties to the Prophet Muhammad, which were previously excluded from power in the elections of 1967-71, embraced the symbols of a new form of politics built on the basis of ethnicity (Bangsa Moro) and religion (Islam) championed by young radicals like Nur Misuari and Hashim Salamat. Against this local socio-political backdrop, added by political discrimination and coercion of Marcos regime, the establishment of the above separatist groups can be understood. Thus, the "Morohood identity" posed by those Muslim 'separatists' is not "naturally invented," but rather "socially constructed" within the frameworks of local socio-political settings. Such ethnic and religious identity has served not only as a vehicle of popular Muslim emancipation but also a means of obscuring the mechanisms of class and ethnic domination. ${ }^{59}$

The data and explanation presented above suggest that Southern Philippines's ethnoreligious separatism and conflict was deeply rooted in, and strongly linked to, the region's instrumental and symbolic resources. As a result, in analyzing the region's violent conflicts and separatist movements one needs to carefully examine both "instrumental and symbolic theory," not simply dub it the Al-Qaeda's networks of "global terrorism." While instrumental theory argues that the nationalism, ethnoreligious separatism, and ethno-religious conflict, were artificial modern phenomena, and "invented" by the elite, the

58 Compare the Southern Philippines's transmigration to that of Indonesia that also provide a fertile ground for rivalry, competition, conflict, and violence in a number of "trouble spots" such as Ambon, Maluku, Papua, Poso, and Aceh. See Gerry van Klinken, Communal Violence and Democratization in Indonesia (London and New York: Routledge, 2007).

${ }^{59}$ Collier, "Dynamics of Muslim Separatism," pp.155-71. 
symbolic theory brings historical explanations based upon ethnic symbols, shared historical and cultural values and myths, including religious values and symbols. The instrumentalist theory, moreover, conceives the ethnic identity as created and constructed by the ethnic elite. ${ }^{60}$ Additionally, the instrumental theory points out that the modernization and economic factors were the fundamental sources of the ethnic conflict. The symbolic theory, by contrast, does not link the recent phenomena of ethnoreligious conflict (as well as separatism and terrorism) to the modern era since there is continuity between the past and the present time. For the symbolists, symbols, myths, and cultural values are the major constructors of ethnicity, thereby serve as a "fertile ground" for the conflict and violence. ${ }^{61}$ Looking at more closely to the Southern Philippines's ethnoreligious political movements, one can find that the region's separatist and terrorist groups built their movements based on the ethnic grievances of instrumentalist and symbolic resources.

Like the Southern Philippines's separatism and terrorism, Indonesia's Islamist terrorism is also deeply rooted in the country's sociopolitical contexts and cultural dynamics. Most current Indonesian jihadists affiliated to JI, for instance, are DI veterans or at least have some links with DI members, families, and associates. ${ }^{62}$ The Dutch anthropologist and Indonesianist Martin van Bruinessen also takes the same line stating that the origins of post-Suharto Indonesia's Muslim radical groups are two relatively indigenous' Muslim political movements- the DI and Masyumi-added by some contemporary transnational Islamic networks. Giving the emphasis on the local politics and history of Indonesia as the nature of recent Muslim political movement, van Bruinessen argues that transnational networks, along which people, ideas, and money move, have become extremely important but "they are not the sole determining factor". ${ }^{63}$ The

\footnotetext{
${ }^{60}$ Ernest Gellner, Thought and Change (London: Weidenfeld and Nicholson, 1964).

${ }^{61}$ Nilufer Duygu Eriten and Jennifer Romine, "Instrumental and Symbolic Resources of Ethnic Conflict: Application of the Kurdish Conflict in Turkey." Normal, IL: Illinois State University, 2008: pp. 1-33. Source: http://lilt.ilstu.edu/critique/Spring\%202008/Eriten_and_Romine_2008.pdf

${ }^{62}$ Ismail, "Al-Qaeda’s Southeast Asia"; Barton, Indonesia's Struggle; ICG (International Crisis Group), "Al-Qaida in Southeast Asia."

63 Martin van Bruinessen, "Genealogies of Islamic Radicalism in Post-Suharto Indonesia," South East Asia Research 10, 20 (2002): pp. 118 and 149.
} 
dynamics of local politics in the Philippines also serve as the backbone for the rise of Muslim separatist movements. Islamist and separatist movements waged by Filipino Moros had been driven by coercion and discriminatory acts against them committed by the dictator Ferdinand Marcos when he had been in power since 1965. ${ }^{64}$

Indeed, regarding the dynamics and history of Indonesian politics, religious-driven violence is not a new phenomenon. The historian M.C. Ricklefs in his Polarizing Javanese Society traces back the "religiousbased violence" to the lengthy conflict between "Kaum Putihan" (lit. the "white group" referring to santri, strict Muslims) and "Kaum Abangan" (lit. the "red people" meaning simply non-santri. It could be Javanese abangan Muslims or non-Muslims) since the mid-nineteenth century. Although prolonged conflicts between these two groups took place since the $19^{\text {th }}$ century, the deep social chasm between the putiban and the abangan, Ricklefs has argued, occurred in the 1950s when such polarization had become 'primordial' and deeply politicized since national, regional, and local religious and political leaders struggled and competed for getting supporters of their political parties. ${ }^{65}$

Moreover, although Al-Qaeda influence on Southeast Asian Muslim terrorists was apparent, ${ }^{66}$ it does not mean that Al-Qaeda and Bin Laden were the only source and agent of terror. As Barton correctly highlights, the origins of terrorist groups such as JI in particular and contemporary radical Islamism in general can be traced back to the foundation of Dewan Dakwah Islam Indonesia (DDIIthe Indonesian Council for Islamic Predication) in 1967, besides Darul Islam and Komando Jihad movements. Founded by prominent Muslim modernist and revivalist Muhammad Natsir (1908-1993), during the early years of the Suharto regime, DDII was the main conduit for Saudi-Wahabi ideas. Barton said that the initial objective of the founding of DDII was "to act as a vehicle for advancing the interests of conservative Islamist politics and blocking Christian

${ }^{64}$ Collier, "Dynamics of Muslim Separatism," pp. 155-71; ICG (International Crisis Group), "The Philippines."

65 M.C. Ricklefs, Polarizing Javanese Society: Islamic and other Visions (c. 1830-1930) (Singapore: NUS Press, 2007), p. 262.

${ }^{66}$ Hefner, "Muslim Democrats and Islamist Violence"; Noorhaidi Hasan, Laskar Jihad: Islam, Militancy, and the Quest of Identity in Post-New Order Indonesia (Ithaca, NY: Cornell Southeast Asia Program Publications, 2006). 
expansion". ${ }^{67}$ Soon after its establishment, the DDII forged close ties with the Saudi-sponsored Rabitah al-'Alam al-Islami (Islamic World League, established in 1962), of which Natsir became one of the ViceChairmen. Already in the 1970s, when Saudi Arabia benefited from the rise in the price of oil, the DDII—with Saudi funding — had begun to spread Wahabi-Salafi teachings by building religious institutions, mosques, and schools, as well as translating and publishing Saudi-Salafi tracts, most of which were notable for their anti-Christian and antiJewish diatribes. ${ }^{68}$ Coincidentally, since the 1970s, Saudi also supported the Deobandi madrasas which have been the training ground for AlQaeda, Taliban, and other militant groups in Pakistan, Kashmir, and Afghanistan. ${ }^{69}$

With the jiha mobilization against the Soviets in Afghanistan, and with the growing irritation in many Arab capitals with U.S. policies in the Middle East, this propaganda took on an even more militantly jihadist tone. ${ }^{70}$ With the end of the Afghanistan campaign and the outbreak of violence in Bosnia, Kashmir, Chechnya, and other Muslim territories, the literature escalated its critique into a full-blown attack on alleged "Jewish-Christian" conspiracies against Islam. Its media organ, Media Dakwah, has become the main instrument of spreading Wahhabism, Salafism, propaganda anti-non Wahabi culture and teachings including the teachings of Islamist thinkers like Qutb, alBanna, and Maududi. ${ }^{71}$ Saudi Arabia, through DDII, also built a college named the Institute for Islamic and Arabic Studies (known as LIPIA) in Jakarta under the supervision of Riyadh-based Imam Muhammad Ibn Saud Islamic University. Since early in the 1980s, the LIPIA has been the vehicle of the propaganda of Wahhabism. Most present-day Indonesian Islamist radical leaders such as Ja'far Umar

\footnotetext{
${ }^{67}$ Barton, Indonesia's Struggle, pp. 90-1.

${ }^{68}$ Hefner, "Muslim Democrats and Islamist Violence," p. 296.

${ }^{69}$ Rashid, Descent Into Chaos.

70 Azyumardi Azra, "Islamic Radical Movements in Indonesia," The Jakarta Post. February 15, 2006.

${ }^{71}$ Stephen Schwartz, The Two Faces of Islam: Saudi Fundamentalism and Its Role in Terrorism (New York: Anchor Books, 2003); Abdurrahman Wahid, "Right Islam vs. Wrong Islam," The W all Street Journal, December 12, $2005 .$.
} 
Thalib $^{72}$ (founder of Laskar Jihad) and Muhammad Habib Riziq (the founder of the Islamic Defender Front) are among the alumni of this institution. ${ }^{73}$ By the 1980s, thus, Islamist ideas from the Middle East and the Indian sub-continental had been translated and were in circulation in Indonesia and elsewhere in Southeast Asia. These mingled and fused with the individual experiential and ideational trajectories of Sungkar and Ba'asyir. Broadly speaking, the injections of al-Banna and Maududi to set up a "vanguard" community to serve as the "dynamic nucleus for true Islamic reformation within the broader society" 74 were long accepted by the Indonesian clerics and radical Islamists. ${ }^{75}$

It is also noteworthy to notice that the DDII is a re-embodiment of Masjumi, an Islamist political party during the Sukarno era that supported the implementation of Islamic Law within Indonesian Constitution and the establishment of an Islamic state in the country. Indeed, the founder of DDII Muhammad Natsir was one of the eminent leaders of Masjumi. Due to some political leaders of Masjumi were involved in a rebel movement held by the Revolutionary Government of the Republics of Indonesia (known as PRRI) against the government, Sukarno banned Masjumi in 1960. It is common among Indonesian scholars that while Sukarno was an admirer of Mustafa Kamal at-Ataturk (1881-1938), Muhammad Natsir was "devotee" of Hasan al-Banna (1906-1949). Tracing back to DDII and Masjumi as one of the roots of the emergence of Islamist radicalism in Indonesia is central in part because most Indonesian radical jihadists had been linked to these organizations. JI figures like Abdullah Sungkar and Abu Bakar Ba'asyir were ex-activists of those groups.

Other Indonesia-based reformist institutions that also contributed to and transformed the shape of the ideology of modern radical Islamists and activists are Al-Irsyad al-Islamiyah (henceforth, Al-

\footnotetext{
${ }^{72} \mathrm{Ja}$ 'far Umar Thalib, in 1987, participated in the Afghan war. He claims to have initially joined the Hizb-i-Islami led by Gulbuddin Hekmatyar, before being sent to assist the Jami'at-i-Islami of Abdur Rasul Sayyaf. See Hasan, Laskar Jihad, p. 71. However, Thalib publicly distanced himself from Bin Laden, not because of his attacks on the U.S. but due to his opposition to the Saudi government. See Hefner, "Muslim Democrats and Islamist Violence," p. 287.

${ }^{73}$ Hefner, "Muslim Democrats and Islamist Violence"; idem., Civil Islam.

${ }^{74}$ Esposito, Unboly War, p. 53.

${ }^{75}$ Ramakrishna, "Delegitimizing Global Jihadi Ideology,” p. 352.
} 
Irsyad) and Persatuan Islam (Persis— the Islamic Union). Al-Irsyad was founded by Indonesian clerics of Arab descents (around 1937) whose main objective was to disseminate strict Islamic teachings and doctrines. ${ }^{76}$ Founded in 1923, Persis was also famous for its conservatism in rejecting all forms of innovations and superstitions in Muslim religious beliefs and practices just like Wahabi in Saudi Arabia and elsewhere. Headquartered in West Java's Bandung (the home-base of DI), Persis has been well-know for its criticism against secularism, pluralism, and liberalism.77 Thus the rise of JI and other radicalized Islamic groups in modern Indonesia was already implicit in the dynamics of these local political settings and histories.

\section{Conclusion}

The description I sketched above confirms what Edward Said calls "travelling idea." Said develops a "travelling theory," saying that the ideas and theories—like people and schools of criticism-travel "from person to person, from situation to situation, and from one period to one another". ${ }^{78}$ Like other ideas and theories, the notions of radical Islamism as the roots of modern "Islamist terrorism" also travel to Southeast Asia's regions, not only from the Middle East, Afghanistan, India, or Pakistan ("international travel") but also from local Southeast Asia itself ("domestic travel"). Such ideas had been brought to Southeast Asia by various agents and actors-both organizations and individuals - who functioned as carriers, transmitters, and transformers of knowledge and a vehicle of changing notions of religious violence and terrorism. JI, ASG, and MILF are only part of those agents that transfer and transform ideas of radical Islamism. Equally important, Bin Laden and Al-Qaeda also served as only one of the resources of Islamic radicalism, not the only ingredient of Islamist terrorism as the "international terrorism experts" assert.

Travelling idea of Islamic radicalism, furthermore, has pursued what Said ${ }^{79}$ called the "phases of acceptance, modification, and a new interpretation" due to different social-political settings. Within the

\footnotetext{
${ }^{76}$ Schwartz, The Two Faces of Islam.

77 Hasan, Laskar Jibad.

${ }^{78}$ Edward Said, The World, the Text, and the Critic (Cambridge, MA: Harvard Univ. Press, 1983), p. 226.

${ }^{79}$ Said, The World, the Text, and the Critic, p. 226.
} 
context of Indonesian history, as I depicted above, the idea of Islamic radicalism has also undergone a process of modification and interpretation of meanings. While Darul Islam's radicalism aimed at the opposition to the Sukarno's 'Old Order' regime and the establishment of an Islamic state separated from the newly Indonesian country, Komando Jihad's religious violence emerged on the scene of Indonesian history and politics was merely as a manifestation of resistance against Suharto-led dictatorial New Order. Contemporary Islamist terrorists, moreover, appeared as the "confrontation" against what they vaguely called the "enemies of Islam." The definition of the "enemies of Islam" definitely differs from one group to another depending on cultural, political, and economic interests of each Islamist group. In the case of Philippines, furthermore, implementation of the idea of "Islamic radicalism" also differs from group to group. MNLF, for instance, took more "nationalistic" (read, Morohood) and "less-Islamic," while MILF was concerned with the idea of "Islamic identity" of Bangsa Moro. For MNLF, the most important thing is the creation of autonomous Southern Philippines (read, political interests), whereas MILF desired to "marry" "Islamness" and Morohood in an Islamic caliphate in the region (read, "symbolic/cultural interests"). ASG, by contrast, is more complicated. Although the initial goal of ASG was to create a "Southeast Asian Islamic caliphate," after the death of its founder, ASG's terrorism and sporadic violence were turned and grounded merely on the basis of the economic interests.

The above depiction suggests that the process of knowledge production and cultural reproduction of Islamic radicalism taking place in different time, space, and social settings has different "meanings," interpretation, and implementation. These Islamist groups, however, have shared the same "values," i.e. the use of "religiously inspired violence," a sort of "sacred bitterness," to achieve their symbolic, political, and economic interests.]

\section{Bibliography}

Abou El Fadl, Khaled. The Great Theft: Wrestling Islam from the Extremists. New York, NY: HarperSanFrancisco, 2005.

Abuza, Zachary. “Al-Qaeda's Asian Web of Terror.” Time (Asia) 160, no. 22 (2002a): pp. 38-40. 
-. "Tentacles of Terror: Al-Qaeda's Southeast Asian Network." Contemporary Southeast Asia 24, 3 (2002b).

--------. Militant Islam in Southeast Asia: Crucible of Terror. Boulder, Colo.: Lynne Rienner, 2003.

Aragon, Lorraine V. "Communal Violence in Poso, Central Sulawesi: Where People Eat Fish and Fish East People." Indonesia 72 (2001): pp. 45-79.

Azra, Azyumardi. "Islamic Radical Movements in Indonesia." The Jakarta Post. February 15, 2006.

Barfield, Thomas. "Problems in Establishing Legitimacy in Afghanistan." Iranian Studies 37, 2 (2004): pp. 263-293.

-. "An Islamic State is a State Run by Good Muslims: Religion as a Way of Life and not an Ideology in Afghanistan." in Robert W. Hefner (ed.). Remaking Muslim Politics: Pluralism, Contestation, and Democratization Princeton and Oxford: Princeton University Press, 2005. pp. 213-239

Barton, Greg. Indonesia's Struggle: Jamaah Islamiyah and the Soul of Islam. Sidney: University of New South Wales Press, 2004.

Bruinessen, Martin van. "Genealogies of Islamic Radicalism in PostSuharto Indonesia." South East Asia Research 10, 20 (2002): pp. 117-154.

Bubalo, Anthony, and Greg Fealy. Joining the Caravan? The Middle East, Islamism, and Indonesia. Lowy Institute Paper No. 5. Sydney: Lowy Institute for International Policy, 2005.

Cohen, Abner. Two-Dimensional Man: An Essay on the Anthropology of Power and Symbolism in Complex Society. Berkeley, CA: University of California Press, 1974.

Colombijn, Freek, and J. Thomas Lindblad (eds). Roots of Violence in Indonesia. Leiden: KITLV Press, 2002.

Collier, Kit. "Dynamics of Muslim Separatism in the Philippines." in Damien Kingbury (ed.).Violence in Between: Conflict and Security in Archipelagic Southeast Asia Clayton and Singapore: Monash Asia Institute and Institute of Southeast Asian Studies, 2005.

Corbin, Jane. Al Qaeda: In Search of the Terror Network. That Shook the World. New York: Thunder Mouth Press/Nation Books, c2002, 
Eriten, Nilufer Duygu, and Jennifer Romine. "Instrumental and Symbolic Resources of Ethnic Conflict: Application of the Kurdish Conflict in Turkey. Normal, IL: Illinois State University, 2008. Source: http://lilt.ilstu.edu/critique/Spring\%202008/Eriten_and_Romine_2008.pdf

Esposito, John L. Unholy War: Terror in the Name of Islam. New York, NY: Oxford University Press, 2002.

Ewans, Martin. Afghanistan: A Short History of its People and Politics. New York, NY: HarperCollins Publishers, 2002.

Fradkin, Hillel, Hussain Haqqani, and Eric Brown (eds). Current Trends in Islamist Ideology. Washington, DC: Hudson Institute, 2005.

Gellner, Ernest. Thought and Change. London: Weidenfeld and Nicholson, 1964.

Gold, Dore. Hatred's Kingdom: How Saudi Arabia Supports the New Global Terrorism. Washington, DC: Regnery Publishing, Inc., 2003.

Goodson, Larry P. "The Taliban Resurface and a New Constitution is Born." Asian Survey 44, 1 (2004): pp. 14-22.

Gopin, Marc. Between Eden and Armageddon: The Future of World Religions, Violence, and Peacemaking. New York, NY: Oxford University Press, 2000.

Gunaratna, Rohan. “Al-Qaeda's Ideology.” in Hillel Fradkin, Hussain Haqqani, and Eric Brown (eds). Current Trends in Islamist Ideology. Washington, DC: Hudson Institute, 2005.

-------. Inside Al-Qaeda: Global Network of Terror. Columbia, NY: Columbia Univ. Press, 2002.

Hasan, Noorhaidi. Laskar Jihad: Islam, Militancy, and the Quest of Identity in Post-New Order Indonesia. Ithaca, NY: Cornell Southeast Asia Program Publications, 2006.

Hedman, Eva-Lotta E. (ed.). Conflict, Violence, and Displacement in Indonesia. Ithaca, NY: Cornel University Southeast Asia Program Publication, 2008.

Hefner, Robert W. Civil Islam: Muslims and Democratization in Indonesia. Princeton and Oxford: Princeton University Press, 2000. -. "Muslim Democrats and Islamist Violence in Post-Soeharto Indonesia." in Robert W Hefner (ed.). Remaking Muslim Politics: 
Pluralism, Contestation, and Democratization. Princeton and Oxford: Princeton University Press, 2005. pp. 273-301

Hoffman, Bruce. Inside Terrorism. New York: Columbia University Press, 1998.

ICG (International Crisis Group). "Al-Qaida in Southeast Asia: the Case of the 'Ngruki Network' in Indonesia." Brussels: ICG Asia Briefing, 2002.

------. "Jihadism in Indonesia: Poso on the Edge." Asia Report no. 127, 24 January 2007.

-. "Indonesia Backgrounder: Why Salafism and Terrorism Mostly Don’t Mix.” Asia Report no. 83, September 152004.

--------. "Jamaah Islamiyah in Southeast Asia: Damaged but Still Dangerous." Asia report No. 63. Jakarta and Brussels: International Crisis Group, 2003.

"The Philippines: Counter-Insurgency versus CounterTerrorism in Mindanao. “ Asia Report No. 152, May 142008.

Ismail, Noor Huda. "Al-Qaeda's Southeast Asia, Jamaah Islamiyah and Regional Terrorism: Kinship and Family Likns." Japan Focus, January 8, 2007: pp 1-11.

Jalali, Ali A. "Afghanistan in 2002: The Struggle to Win the Peace." Asian Survey 43, 1 (2003): pp. 174-185.

Juergensmeyer, Mark. Terror in the Mind of God: The Global Rise of Religious Violence. Berkeley, CA: University of California Press, 2003.

Kingsbury, Damien (ed.). Violence in Between: Conflict and Security in Archipelagic Southeast Asia. Clayton and Singapore: Monash Asia Institute and Institute of Southeast Asian Studies, 2005.

Klinken, Gerry van. Communal Violence and Democratization in Indonesia. London and New York: Routledge, 2007.

Mamdani, Mahmood. Good Muslim, Bad Muslim: America, the Cold War, and the Roots of Terror. New York: Pantheon Books, 2004.

McKenna, Thomas. Muslim Rulers and Rebels: Everyday Politics and Armed Separatism in the Southern Philippines. Berkeley, CA: University of California Press, 1998. 
Mousalli, Ahmad S. Radical Islamic Fundamentalism: The Ideological and Political Discourse of Sayyid Qutb. Beirut: American University of Beirut, 1992.

Nordholt, Henk Schulte, and Gerry van Klinken (eds). Renegotiating Boundaries: Local Politics in Post-Suharto Indonesia. Leiden: KITLV Press, 2007. pp. 562

Olzak, Susan. "Ethnic, Racial, and Nationalist Movements." in The Blackwell Encyclopedia of Sociology, vol. III, ed. by George Ritzev. Malden, MA: Blackwell Publishing, 2007.

Pipes, Daniel. In the Path of God: Islam and Political Power. New York: Basic Books, 1982.

Rabasa, Angel. Beyond Al-Qaeda: Countering Terrorist and other nonTraditional Threats. Santa Monica, CA: The RAND Corporation, 2007.

Political Islam in Southeast Asia: Moderates, Radicals, and Terrorist. Curzon: Routledge, 2003.

Ramakrishna, Kumar. "Delegitimizing Global Jihadi Ideology in Southeast Asia." Contemporary Southeast Asia 27, 3 (2005): pp. 343-69.

Rashid, Ahmad. Taliban: Militant Islam, Oil and Fundamentalism in Central Asia. Yale: Yale University Press, 2001.

---------. Descent Into Chaos: The United States and the Failure of Nation Building in Pakistan, Afghanistan, and Central Asia. New York: Viking Penguin, 2008.

Ricklefs, M.C. Polarizing Javanese Society: Islamic and other Visions (c. 18301930). Singapore: NUS Press, 2007.

Roy, Oliver. "The Mujahidin and the Future of Afghanistan." in John L. Esposito (ed.). The Iranian Revolution: Its Global Impact. Florida: Florida International Univ. Press, 1991.

---------. Islam and Resistance in Afghanistan. Cambridge: Cambridge University Press, 1990.

Rubin, Barnett R. The Fragmentation of Afghanistan: State Formation and Collapse in the International System. New Haven and London: Yale University Press, 1995. 
Sageman, Marc. Understanding Terror Networks. Philadelphia, PA: Univ. of Pennsylvania Press, 2004.

Said, Edward. The World, the Text, and the Critic. Cambridge, MA: Harvard Univ. Press, 1983.

Schwartz, Stephen. The Two Faces of Islam: Saudi Fundamentalism and Its Role in Terrorism. New York: Anchor Books, 2003.

Shadid, Anthony. Legacy of the Prophet: Despots, Democrats, and the New Politics of Islam. Boulder, CO: Westview, 2002.

Sidel, John. Riots, Pogroms, Jihad: Religious Violence in Indonesia. Ithaca and London: Cornell University Press, 2006.

Thayer, Carlyle A. "Leadership Dynamics in Terrorist Organizations in Southeast Asia." Kuala Lumpur, Malaysia: Center for Defense Leadership Studies, 2005.

Wahid, Abdurrahman. "Right Islam vs. Wrong Islam." The Wall Street Journal, December 12, 2005. 